
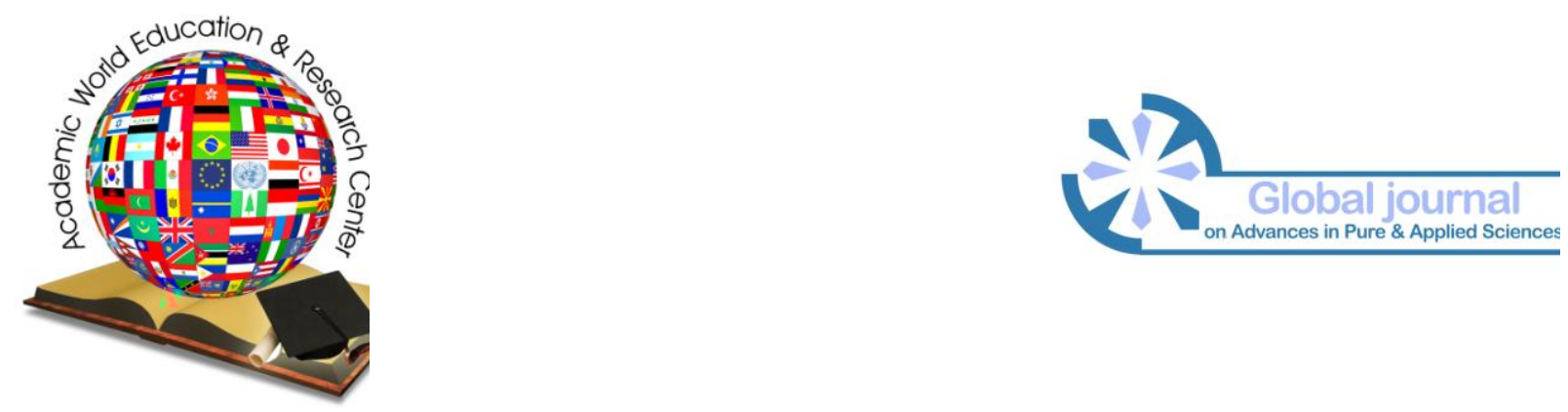

Efes Sürmeli Hotel \& Convention Center - İzmir, Kuşadası, Turkey

\title{
Curcumin: The miraculous golden ingredient of Indian saffron
}

Indrani Kalkan*,

Suggested Citation:

Pure \& Applied Sciences.

Global Journal on Advances in

(C)2016

Abstract

Curcuma longa)

diferuloyl methane

Manganese.

$*$

İndrani Kalkan, 


\section{Introduction}

1.1. Curcumin and its Traditional Uses

2. Sources of Evidence: Literature Search Methods

"Turmeric" or "Curcumin"

"Cancer" OR "Alzheimer's disease" OR "Cardiovascular Heart Diseases" OR "Arthiritis" OR "degenerative diseases". More than 45 original research and review articles in English language dated

\section{Curcumin}

3.1. Chemistry and bioavailability

diferuloyl methane 

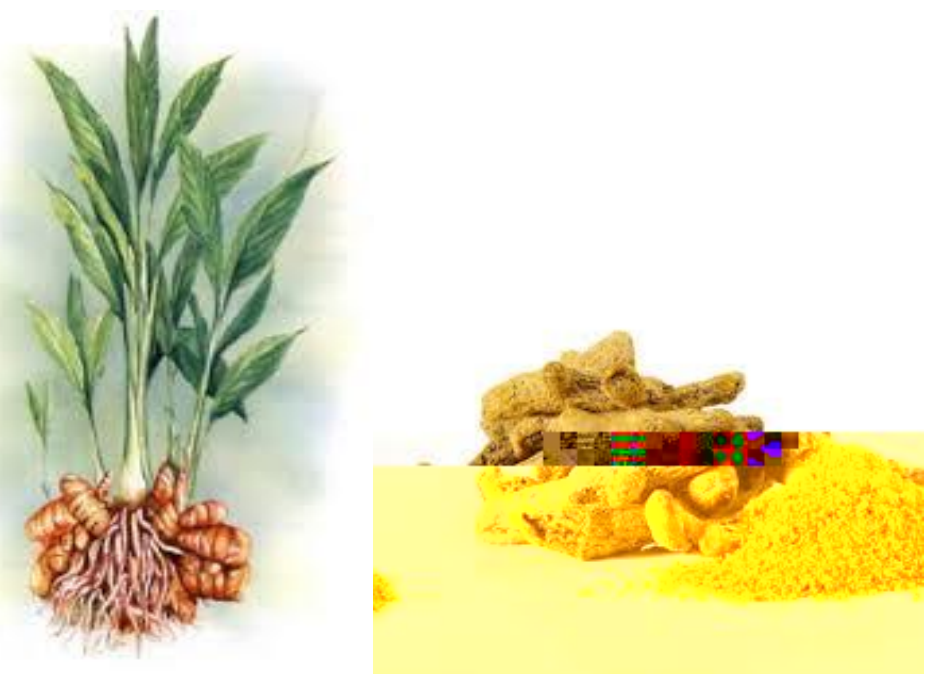

4. Anti-oxidative activity of Curcumin 
<smiles>COc1cc(/C=C/C(=O)CC(=O)/C=C/c2ccc(O)c(OC)c2)ccc1O</smiles>

\section{Anti-Inflammatory Effects}

degererative disease including cardiovascular heart disease, cancer, metabolic syndrome, Alzheimer's

associated with inflammatory skin conditions and allergies. Curcumin's anti

other than cancer, with inflammation constituents including cardiovascular diseases, Alzheimer's

\section{Curcumin's Effect on Chronic Inflammatory Diseases}

6.1 Cardiovascular Heart Diseases: 


\subsection{Cancer}

in vitro in vivo

\subsection{Neurogenerative disorders}

, Parkinson's disease,

In vivo

6.4. Diabetes and Glucose metabolism 


\subsection{Digestive Diseases}

\section{Other Effects}

КB pathway inhibition. The herb's volatile oils 


\section{Conclusions}

\section{References}

Nutrition Today 45

Indian journal of pharmacology 43

Cellular and Molecular Life Sciences 65

Rom J Biol-Plant Biol 55

Archives of physiology and

biochemistry 114

Anticancer

research 21

BMC complementary and alternative medicine 6

The international journal of biochemistry \& cell biology 41

Molecules 20

and development 128

Mechanisms of ageing

International journal of cardiology 133

cardiovascular pharmacology and therapeutics

Journal of

Journal of clinical psychopharmacology 28 
targets and therapeutic uses of curcumin in health and disease

The molecular

Alzheimer's disease 10

Bowman, A. B., Kwakye, G. F., Hernández, E. H., \& Aschner, M. (2011). Role of manganese in Journal of Trace Elements in Medicine and Biology 25

Journal of Pure \& Applied Science \& Technology 11

Journal of medicinal food 8

Endocrinology 149

Diabetes research and clinical practice 80

Phytomedicine 21

Science of Food and Agriculture 92

Journal of the

Pharmacology Biochemistry and Behavior 99

Biofactors 39

García Niño, W. R., \& Pedr Chaverrí, J. (2014). Protective effect of curcumin against heavy metals Food and Chemical Toxicology 69

. Journal of neuroscience research, 92 